\title{
SYNTHESIS AND PHYTOTOXIC PROFILE OF A NEW TETRAOXANE DESIGNED FROM A COMMERCIAL AUXIN
}

Isabel V. Antolínez ${ }^{\mathrm{a}}$, Luiz C. A. Barbosa ${ }^{\mathrm{a}, \mathrm{b}, *, \odot}$, Célia R. A. Maltha ${ }^{\mathrm{b}}$, Gustavo A. M. M. Pereira ${ }^{\mathrm{c}}$ and Antônio A. Silva ${ }^{\mathrm{c}}$ a'Departamento de Química, Universidade Federal de Minas Gerais, Campus Pampulha, 31270-901 Belo Horizonte - MG, Brasil bDepartamento de Química, Universidade Federal de Viçosa, 36570-900 Viçosa - MG, Brasil 'Departamento de Ciências Agrárias, Universidade Federal de Viçosa, 36570-900 Viçosa - MG, Brasil

Recebido em 12/02/2020; aceito em 08/04/2020; publicado na web em 20/05/2020

\begin{abstract}
Modern agriculture relies on the massive use of agrochemicals, including herbicides. Despite their effectiveness, a continuous use of herbicides sharing the same target has resulted in the selection of weed biotypes resistant to such chemicals. To cope with this problem, the development of new herbicides is an urgent requirement. In this work we applied the Active compound Derivatization Method (ADM) strategy to develop a new tetraoxane (5), derived from the synthetic auxin 2-(naphtalen-1-yl)acetic acid (NAA). Greenhouse bioassays showed that $\mathbf{5}$ caused chlorosis, necrosis and leaf epinasty in Cucumis sativa. Furthermore, this compound, at the concentration of $1.25 \times 10^{-5} \mathrm{~mol} \mathrm{~L}^{-1}$, inhibited the growth of important weeds such as Bidens pilosa, Iponomea acuminate, Solanum americanum and Althernantera ficoidea. For some weeds, the compound effect was higher or comparable to those caused by commercial glyphosate and imazethapyr. In addition, degradation studies revealed that $\mathbf{5}$ is transformed into NAA. The results also showed that $\mathbf{5}$ could act as photosynthesis inhibitor and as an auxin herbicide. In summary, we have discovered a new compound that may be a useful lead for the development of a commercial herbicide.
\end{abstract}

Keywords: weed control; 2-(naphthalen-1-yl)acetic acid; tetraoxane; new herbicide design; organic peroxide.

\section{INTRODUCTION}

Since the discovery of phytotoxic activity of phenoxyacetic acid derivatives in the 1940s, the use of synthetic organic herbicides became the most reliable and cost-effective strategy to control weeds in agricultural and non-agricultural areas. ${ }^{1}$ During the last decades some new commercial herbicides, with new modes of actions, have been developed. ${ }^{2,3}$ Despite such success, the repetitive and massive use of herbicides has led to the appearance of an increasing number of weeds resistant to one or more products. ${ }^{4,5}$ In order to overcome such problems, and cope with the increasing demand for food required for the continuously rising human population, the agrochemical industries and the academy must find new herbicides, focusing their efforts on finding compounds with new modes of action. ${ }^{6,7}$

In line with such global efforts, our research group has been using a diversity of natural products as a model for the development of new compounds endowed with phytotoxic activities (Figure 1). ${ }^{8-11}$ This strategy has been used by many authors, including the group led by Duke, that has demonstrated the ecologic interactions played by artemisinin (1), a natural product isolated from the plant Artemisia апnиa. They reported the phytotoxic activity of artemisinin against species such as Lactuca sativa and Raphanus sativa ${ }^{12}$ Artemisinin owes its biological activities largely to the peroxide bond in its structure. However, its commercial use as herbicide is hampered by the cost of large-scale production due to its complex structure. ${ }^{13}$ Inspired by such investigations, we have pioneered the discovery of a new class of herbicides candidates, of general structure 2 , bearing a 1,2,4-trioxolane (ozonide) moiety. These compounds have a peroxide group similar to that found in the 1,2,4-trioxane artemisinin. ${ }^{14}$ Further investigations in our group resulted in the discovery that 1,2,4,5-tetraoxanes, as illustrated by $\mathbf{3}$, are potent herbicides against the weeds Euphorbia heterophilla and Brachiaria brizantha. ${ }^{15,16}$

*e-mail: 1cab@ufmg.br

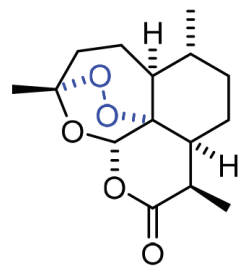

1<smiles>O=C(O)Cc1cccc2ccccc12</smiles>

4a - NAA

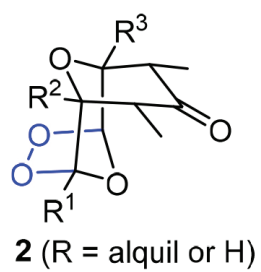<smiles>C1CCC2(CC1)OOC1(CCCCC1)OO2</smiles>

3<smiles>c1ccc2c(CC3OOC4(CCCCC4)OO3)cccc2c1</smiles>

Figure 1. Structures of artemisinin (1), general formula of ozonides (2), tetraoxane (3), 2-(naphthalen-1-yl)acetic acid (NAA) (4a), and the new tetraoxane (5) designed by "Active compound Derivatization Method" (ADM)

In addition to the use of natural products and other classical methods applied to the discovery of new agrochemicals, a new concept of "Intermediate Derivatization Methods" (IDM) has been described. ${ }^{17}$ Among the IDM strategies the so called "Active compound Derivatization Method" (ADM) involves the modification of a known commercial agrochemical or other active compound via a diversity of chemical reactions. ${ }^{17}$ Due to the successful examples of IDM strategies in the discovery of new agrochemicals, we sought to apply the ADM method using the 2-(naphthalen-1-yl)acetic acid (4a, NAA) as a starting material.

The NAA and its salts and esters were introduced in the early 1960s as plant growth regulators (PGR). ${ }^{3}$ The NAA belongs to a class of synthetic auxins and its PGR activity is due to the structural 
similarity with the plant hormone 2-(1H-indol-3-yl)acetic acid (IAA) ${ }^{1,18}$ Like other hormones, when applied at higher concentration, it has herbicidal activity. ${ }^{19}$ Although the mechanism of action of auxinic herbicides is not well elucidated, it is known that the compounds are transported to the tissues due the high affinity between auxin receptors and the herbicide. ${ }^{20}$

Our proposal was to replace the carboxylic function of NAA by the tetraoxane core to produce compound $\mathbf{5}$. We envisaged that the tetraoxane moiety would impart the compound with some useful biological activity as previously reported..$^{15}$ Once in the plant tissue, the tetraoxane could cause the expected toxic effect due to the peroxide core. If metabolized in the plant tissue producing NAA, its effect would be further increased. Also, if it is degraded in the soil it could produce NAA via the corresponding aldehyde. In this case, the tetraoxane would therefore act as a pro-herbicide. ${ }^{21,22}$ Consequently, we expect the hybrid compound $\mathbf{5}$ to have a more prolonged effect than NAA and to act via a different mechanism.

In order to test our hypothesis, in this study, we report the synthesis of the new tetraoxane $\mathbf{5}$ and its phytotoxic activity against several plant species, including four important weeds for the agricultural market in Brazil. We also report the results of a degradation study of 5 under laboratory conditions.

\section{RESULTS AND DISCUSSION}

\section{Synthesis of tetraoxane derivative of 2-(naphtalen-1-yl)acetic acid (5)}

The synthesis of tetraoxane $\mathbf{5}$ is outlined in Scheme 1. The required aldehyde $\mathbf{6}$ was obtained from the commercially available 2-(naphtalen-1-yl)acetic acid (4a). The initial attempt to convert $\mathbf{4 a}$ into 6 involved its quantitative transformation into the corresponding methyl ester $\mathbf{4 b}$, followed by reduction with DIBAL. Despite some reports on the direct conversion of methyl esters into the corresponding aldehydes, in our hands the alcohol was obtained as the sole product. ${ }^{23}$<smiles>[R]OC(=O)Cc1cccc2ccccc12</smiles>

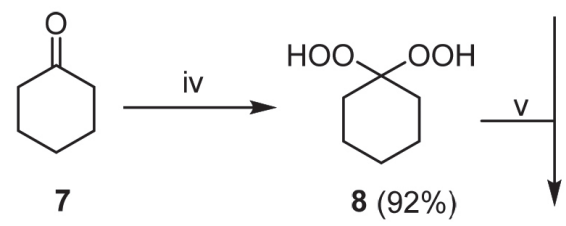

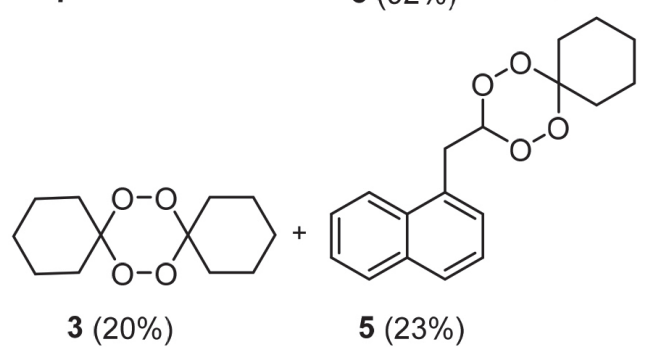

Scheme 1. Reagents and conditions: i) $\mathrm{Et}_{3} \mathrm{~N}, \mathrm{SOCl}_{2}, \mathrm{MeOH}, 25^{\circ} \mathrm{C}, 2 \mathrm{~h}$; ii) $\mathrm{LiAlH}_{4}, \mathrm{THF}, 25^{\circ} \mathrm{C}, 12 \mathrm{~h}$; iii) $\mathrm{DMP}, \mathrm{CH}_{2} \mathrm{Cl}_{2}, 25^{\circ} \mathrm{C}, 2 \mathrm{~h}$; iv) $\mathrm{H}_{2} \mathrm{O}_{2} 56 \%(\mathrm{v} / \mathrm{v})$, $\mathrm{SnCl}_{2}(20 \mathrm{~mol} \%), \mathrm{THF}, 25^{\circ} \mathrm{C}, 1.5 \mathrm{~h}$; v) $\mathrm{H}_{2} \mathrm{SO}_{4}, \mathrm{CH}_{3} \mathrm{CN}, \mathrm{CH}_{2} \mathrm{Cl}_{2},-78^{\circ} \mathrm{C}$ to $25^{\circ} \mathrm{C}, 4 \mathrm{~h}$
Based on this result, the acid $\mathbf{4 a}$ was treated with $\mathrm{LiAlH}_{4}$ and the alcohol formed was subsequently oxidized. Initial Swern oxidation resulted in total consumption of the alcohol, affording the required aldehyde in a consistent but poor yield (9\%). Such low yield could be due to degradation of the aldehyde via initial aldol condensation in the presence of triethylamine in the reaction medium..$^{24,25}$

Further attempt to oxidize the alcohol involved the use of PDC at room temperature, but under these conditions the alcohol proved inert; increasing the temperature to $45^{\circ} \mathrm{C}$ caused the decomposition of the starting material. ${ }^{26}$

A more successful approach to achieving the oxidation involved the use iodine hypervalent reagents. First, oxidation with BAIB (bisacetoxyiodobenzene) and TEMPO (2,2,6,6-tetramethylpiperidin-1yl)oxyl as catalyst produced 6 in $63 \%$ yield. Further improvement was achieved using Dess-Martin reagent, that afforded the desired product in $86 \%$ yield after $2 \mathrm{~h}$ of reaction. ${ }^{27}$ It is important to highlight that the purification of aldehyde $\mathbf{6}$ by silica gel column fractionation was not efficient due to its instability under acid condition. We found that the best way to purify $\mathbf{6}$ was by distillation at atmospheric pressure.

Having obtained aldehyde 6 , we focused on the preparation of the intermediate 8 . This compound has been previously produced in $76 \%$ yield from cyclohexanone and hydrogen peroxide (concentration of $30 \% \mathrm{v} / \mathrm{v}$ ) and $\mathrm{AlCl}_{3}$ as catalyst. ${ }^{15}$ We have screened several catalyst and solvents in order to optimize this reaction and found that the use of a more concentrated solution of hydrogen peroxide (aqueous $\mathrm{H}_{2} \mathrm{O}_{2}$ at $56 \%$ v/v) and $\mathrm{SnCl}_{2}(20 \mathrm{~mol} \%)$ as catalyst afforded 8 in a reproducible yield of $92 \%$ (see Table $1 \mathrm{~S}$ for other experimental conditions). This compound was obtained as a low melting point solid, that was crystalized before use in the next reaction. ${ }^{28}$

With the intermediates $\mathbf{6}$ and $\mathbf{8}$ in hand, their conversion into the required non-symmetric tetraoxane $\mathbf{5}$ was investigated. Initially, the intermediates (6 and 8 ) were dissolved in acetonitrile containing a catalytic amount of sulfuric acid. ${ }^{29}$ Even leaving the reaction from $0{ }^{\circ} \mathrm{C}$ to room temperature for a long period of time (up to 72 hours), the required product was not formed and only around $20 \%$ of the symmetric tetraoxane $\mathbf{3}$ was obtained. Knowing that the preparation of non-symmetric tetraoxane is usually a difficult process, affording the required products in low yields, we investigated this reaction under a variety of conditions. After several experiments (see Table $2 \mathrm{~S}$ for details), we found that the use of dichloromethane as solvent and starting the reaction at $-78{ }^{\circ} \mathrm{C}$, under catalysis of sulfuric acid, the required product $\mathbf{5}$ was obtained in $23 \%$ yield, along with $20 \%$ of $\mathbf{3}$ (Scheme 1). ${ }^{29,30}$

Compound $\mathbf{5}$ was isolated as a white solid and had its structure confirmed by extensive spectroscopic analysis. The ${ }^{1} \mathrm{H}-\mathrm{NMR}$ spectrum showed a multiplet between 1.28-1.66 ppm and a triplet at $2.37 \mathrm{ppm}$, signals assigned to the hydrogens of the cyclohexane ring. A doublet at $3.33 \mathrm{ppm}(J=4.7 \mathrm{~Hz})$ and a triplet at $6.14 \mathrm{ppm}$ $(\mathrm{J}=4.7 \mathrm{~Hz})$ are assigned to the $\mathrm{CH}_{2}-\mathrm{CH}$ side chain moiety (H-9 and $\mathrm{H}-10$, respectively). Further signals due to the naphthalene core were observed between 7.26-8.01 ppm. In the ${ }^{13} \mathrm{C}-\mathrm{NMR}$ spectrum a total of 18 signals were observed. The signals between 22.0-34.0 ppm are associated with the cyclohexane ring and carbon C-9. Next, the signals at $108.3 \mathrm{ppm}$ and $109.1 \mathrm{ppm}$ are assigned to $\mathrm{C}-10$ and $\mathrm{C}-13$ of the tetraoxane core. Finally, the ten signals between 122.00-135.00 were observed for the naphthalene ring (see Figures $1 \mathrm{~S}$ and $2 \mathrm{~S}$ ).

At this stage, considering that the preparation of non-symmetric tetraoxane is a well- known, low-yielding process, we did not invest more time to further optimize the reaction. Despite the limited overall yield for the preparation of tetraoxane $\mathbf{5}$, it was produced in gram quantities, sufficient for biological evaluation as described in the next section. ${ }^{30}$ 
It is worth mentioning at this point that due to the difficulty in preparing non-symmetric tetraoxanes, an interesting target to be biologically evaluated would be the symmetric tetraoxane derived from 6. However, such synthesis was not viable since aldehydes are prone to oxidation to the corresponding acid under the conditions required to prepare the 1,1-dihydroperoxy intermediates. We have investigated several experimental conditions to convert aldehyde into the corresponding symmetric tetraoxanes, without success. ${ }^{31}$

\section{Herbicidal activity}

The pre-emergency herbicidal activity of $\mathbf{5}$, along with the commercial herbicides 2-(naphtalen-1-il)acetic acid (NAA, 4a), glyphosate (GLY) and imazethapyr (IMA) was evaluated. The commercial products GLY and IMA were chosen as positive references since they are widely used in Brazil in different cultures, including soybean. Although they are highly effective, there is a concern due to the increase of weeds developing resistance to these herbicides. ${ }^{4}$ In addition, many studies suggest that GLY might be a carcinogenic agent, while IMA is highly persistence in soil, causing several environmental issues. ${ }^{32,33}$ Therefore, to find new compounds that can replace such commercial products is an important area of research. So, due to such constrains we included GLY and IMA as positive control in our experiments in order to evaluate their effectiveness in comparison with the new tetraoxane.

Considering the possibility that during the experiment 5 could be degraded into its precursors $\mathbf{6}$ and $\mathbf{8}$, these two compounds were also assayed. The initial greenhouse bioassays were carried out using Cucumis sativa and Sorghum bicolor as target species due to their high sensitivity to herbicides. ${ }^{34}$ The compounds were tested at the dose of $8.3 \times 10^{-6} \mathrm{mmol}$ per gram of substrate (a solution of 0.125 mmol L ${ }^{-1}$ was employed). All compounds caused some inhibition on the germination of both species (Table 1). When tested on $C$. sativa, compound $\mathbf{5}$ was as active ( $40 \%$ of germination) as IMA, while all the others reduced the germination to 53-60\%. The test against $S$. bicolor revealed that $\mathbf{5}$ caused $20 \%$ inhibition on germination, being less active than IMA and GLY, and as active as NAA. On the other hand, precursor 6 inhibited the germination by $80 \%$, being as active as IMA, while 8 ( $40 \%$ inhibition) was more active than NAA. For comparison, the side product 3 inhibited the germination of both plants by $40 \%$ (see Table 9S), being less effective than $\mathbf{5}$ against $C$. sativa and more active against $S$. bicolor.

With regard to root inhibition, tetraoxane $\mathbf{5}$ caused little or no effect on both species, but inhibited the shoot growth of $C$. sativus and S. bicolor by $44.2 \%$ and $61.1 \%$, respectively. In general, compound 3

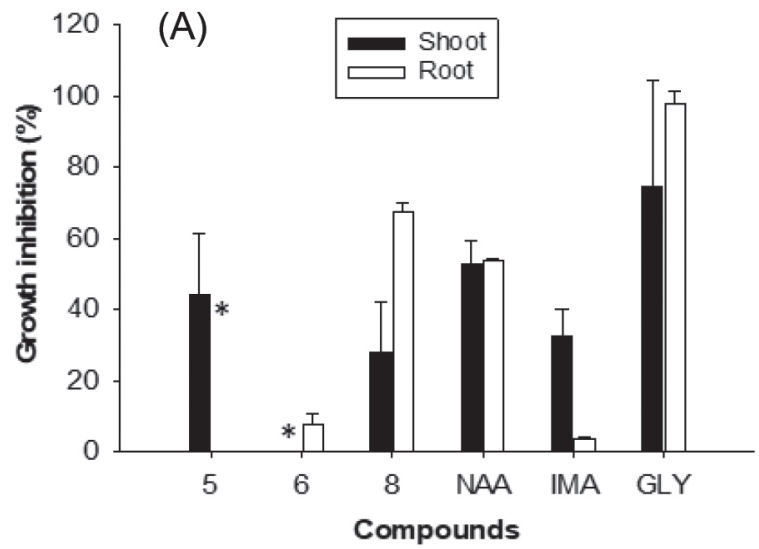

Table 1. Percentage of germination of Cucumis sativa and Sorghum bicolor in the presence of the new compounds $\mathbf{5 , 6}$ and $\mathbf{8}$, and commercial herbicides, after five days of experiment

\begin{tabular}{ccc}
\hline Compound & C. sativa & S. bicolor \\
\hline $\mathbf{5}$ & 40 & 80 \\
$\mathbf{6}$ & 60 & 20 \\
$\mathbf{8}$ & 53 & 60 \\
NAA & 40 & 80 \\
IMA & 60 & 20 \\
GLY & 53 & 66 \\
\hline
\end{tabular}

was less effective than $\mathbf{5}$ in inhibiting the shoot of both species (see Tables $3 \mathrm{~S}$ and $4 \mathrm{~S}$ ). This level of activity is comparable or higher than the reference NAA. The reference GLY is more active in comparison with the synthetic compounds $\mathbf{5 , 6}$ and $\mathbf{8}$ for $C$. sativa, while IMA is more effective against $S$. bicolor (Figure 2). In general, precursor 6 was not active for both species, while the peroxide 8 caused $67.3 \%$ inhibition on the root growth of $C$. sativa, being more active in comparison with NAA, and IMA, while it caused little effect $(22.7 \%)$ on the roots of S. bicolor.

Having demonstrated that the hybrid peroxide 5 caused a significant inhibition on shoot formation in C. sativa and S. bicolor, we further investigated the activities of all compounds against the weeds Iponomea acuminate, Bidens pilosa, Solanum americanum and Alternanthera ficoidea (Figure 3). Those weeds are ubiquitous in crops plantations such as soybean, cotton, and tomatoes, all of them being cultivated in large areas in Brazil and corresponding to a high proportion of the national agricultural production. ${ }^{35-38}$ So, controlling such species is essential to guarantee a maximum profit from such crops.

In the case of B. pilosa (Figure 3A) compound $\mathbf{5}$ was as potent as NAA as root inhibitor ( $46.7 \%$ inhibition), but had a greater effect on shoot, causing $32.7 \%$ inhibition, against $22.2 \%$ caused by NAA. It was found that $\mathbf{6}$ and $\mathbf{8}$ caused some inhibition on both plant parts, but the effect was less pronounced in comparison with $\mathbf{5}$. None of the compounds were as active as IMA and GLY, that caused more than $66 \%$ inhibition on roots and more than $48.9 \%$ inhibition on shoot. When 5 was tested at a higher dose $\left(33.2 \times 10^{-6} \mathrm{mmol}\right.$ per gram of substrate, corresponding the use of a $1.00 \mathrm{mmol} \mathrm{L}^{-1}$ solution) it caused at least $53.6 \%$ inhibition on roots growth and $95.5 \%$ on the shoot.

In the case of I. acuminate (Figure 3B), the commercial references NAA and IMA were the most active against this weed, causing more

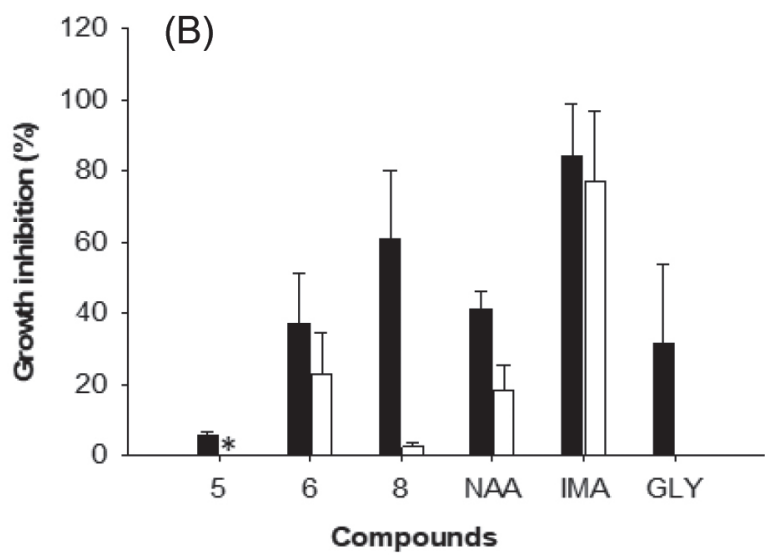

Figure 2. Effect of compounds 5, 6 and $\mathbf{8}$ on the growth inhibition of shoot and roots of Cucumis sativa (A), and Sorghum bicolor (B). Values were calculated based on the dry weight of the control. Commercial herbicides used as positive control were: 2-(naphthalen-1-yl)acetic acid (NAA), imazethapyr (IMA), glyphosate (GLY). The compounds were tested at $0.125 \mathrm{mmol} L^{-1}$. The presence of an asterisk (*) instead a bar indicates stimulation (see Tables $2 S-7 S$ for full data) 

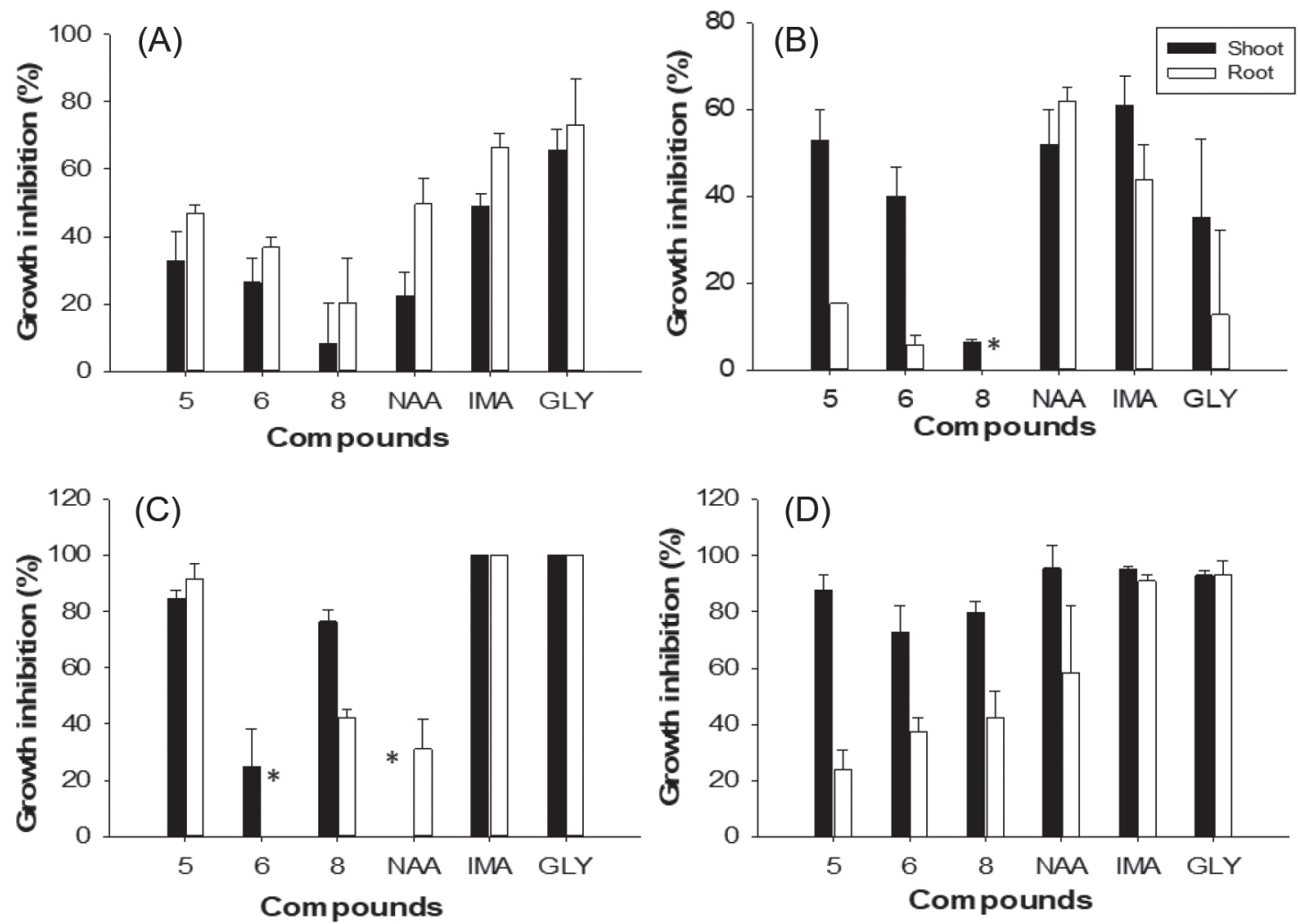

Figure 3. Effect of compounds $\mathbf{5 , 6}$ and $\mathbf{8}$ on the growth inhibition of shoot and roots of Bidens pilosa $(A)$, Iponomea acuminate (B), Solanum americanum (C) and Altenanthera ficoidea (D). Values were calculated based on the dry weight of the control. Commercial herbicides used as positive control: 2-(naphthalen1-yl)acetic acid (NAA), imazethapyr (IMA) and glyphosate (GLY). The compounds were tested at $0.125 \mathrm{mmol} \mathrm{L}^{-1}$. The presence of an asterisk (*) instead a bar indicates stimulation (see Tables 2S-7S for full data)

than $40 \%$ inhibition on roots and shoots, while GLY caused only $35 \%$ inhibition on shoots and had little effect on roots. In comparison, tetraoxane $\mathbf{5}$ caused $\mathbf{5 2 . 9 \%}$ inhibition on shoot growth, equivalent to the activity of NAA. For $\mathbf{5}$ only a small inhibitory effect on roots development was observed. The aldehyde $\mathbf{6}$ caused $40 \%$ inhibition on shoot growth, with no effect on roots. On the other hand, 8 caused unexpected root growth promotion, and no significant effect on the shoots. The root growth promotion is not easily explained, since the peroxide is expected to generate radicals that are toxic to plants and several other organisms. ${ }^{39}$ Despite the relatively small standard deviation $(-53.9 \pm 7.7 \%)$ this should be further investigated in order better understand the effect of hydroperoxyacetals on the plant growth.

The specie S. americanum (Figure 3C) showed to be very sensitive to IMA and GLY, with both herbicides causing $100 \%$ inhibition on the development of roots and shoot. Commercial herbicide NAA, at the dose of $8.3 \times 10^{-6} \mathrm{mmol}$ per gram of substrate $\left(0.125 \mathrm{mmol} \mathrm{L}^{-1}\right.$ solution employed), promoted the shoot growth by $141.2 \%$, while inhibited the roots by $31.1 \%$. As is well known, low concertation of auxin in plants stimulates its growth, due their participation in ethylene biosynthesis and abscisic acid synthesis. ${ }^{19}$ In contrast to NAA, compound $\mathbf{5}$ was very effective in controlling $S$. americanum, inhibiting shoot and roots by more than $84.5 \%$. The aldehyde 6 caused a small effect on the shoot development (25\% inhibition) but promoted a root growth by $63 \%$, a similar effect observed for NAA on shoot. On the other hand, the hydroperoxide $\mathbf{8}$ also caused a pronounced inhibition on the whole plant. Finally, when tested against $A$. ficoidea (Figure 3D), all compounds inhibited the shoot growth by at least $72.9 \%$, with $\mathbf{5}$ causing $87.5 \%$ inhibition at $0.125 \mathrm{mmol} \mathrm{L}^{-1}$. Contrary to IMA and GLY, the effects of $\mathbf{5 , 6}$ and $\mathbf{8}$ on root inhibition were less pronounced.

In comparison with the activity of previously reported compound $\mathbf{3}$, the new tetraoxane $\mathbf{5}$ is more potent against all tested weeds (see Tables 3S-8S), except in the case of the roots of A. ficoidea (3 inhibited 38\% of root growth, against 24\% inhibition caused by $\mathbf{5}$ ).

Besides the quantitative inhibitory effects reported for all compounds, a qualitative visual evaluation was carried out by three trained experts on weed science. ${ }^{40}$ For this evaluation, the observed phytotoxic effect was analyzed and rated on a scale from zero (no effect) to 100 (plant death). In order to have a better evaluation of the changes, this assay was carried out using a solution of $1 \mathrm{mmol} \mathrm{L}^{-1}$, and the averages of three independent evaluations are presented on Table 2. All plant species were very sensitive to IMA $(\geq 95 \%$ intoxication), while for GLY some species were less affected ( $\geq 80 \%$ inhibition). The major reference NAA also caused $\geq 80 \%$ intoxication on most species, except in the case of $S$. bilocor, that was also resistant to peroxides $\mathbf{5}$ and $\mathbf{8}$ and aldehyde $\mathbf{6}$. In general, peroxide $\mathbf{5}$ was as active as NAA, while $\mathbf{8}$ had a pronounced effect only against $S$. americanum and $C$. sativa. The hydroperoxyacetal 8 was very effective only against $S$. americanum.

Among all the evaluated species, $C$. sativa presented the most pronounced visual changes. The positive control NAA caused leaf epinasty and root nodulation, ${ }^{1}$ both typical effects of auxinic herbicides (Figure 4B). In the case of $\mathbf{5}$ the leaf epinasty was also observed. In addition, this compound also caused chlorosis and necrosis in the aerial parts; these changes were also observed in plants treated with peroxide $\mathbf{8}$ (Figures $4 \mathrm{C}$ and $4 \mathrm{D}$ ). ${ }^{41}$

Such results match with changes caused by artemisinin. In fact, investigation on the mode of action of artemisinin revealed that the peroxide bond in its structure is responsible for the overproduction of reactive oxygen species. ${ }^{42}$ High concentration of reactive oxygen species (ROS) can degenerate, among others, lipid peroxidation and cell division. In the case of artemisinin, it can affect photosystem II 
Table 2. Percentage of intoxication of the target species treated with $1 \mathrm{mmol} \mathrm{L}^{-1}$ solution of the compounds after 22 days of experiment. Values are reported according to the ALAM scale

\begin{tabular}{|c|c|c|c|c|c|c|}
\hline Compound & C. sativa & S. bicolor & B. pilosa & I. acuminate & S. americanum & A. ficoidea \\
\hline 5 & 90 & 0 & 90 & 80 & 100 & 86 \\
\hline 6 & 77 & 0 & 37 & 0 & 95 & 33 \\
\hline 8 & 50 & 0 & 0 & 0 & 95 & 60 \\
\hline NAA & 80 & 0 & 90 & 80 & 100 & 93 \\
\hline IMA & 100 & 100 & 95 & 100 & 100 & 100 \\
\hline GLY & 80 & 90 & 95 & 80 & 100 & 100 \\
\hline
\end{tabular}

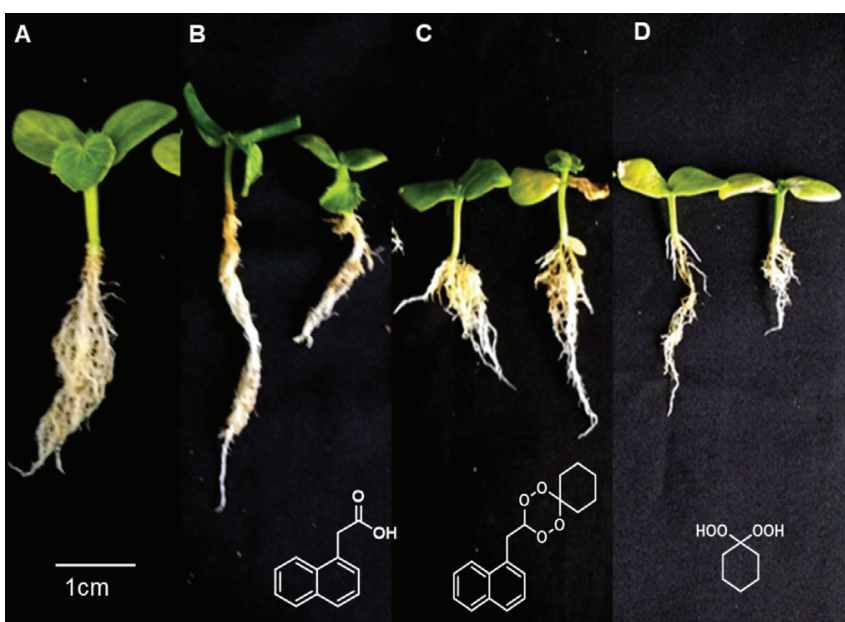

Figure 4. Visual changes or effects caused by compounds NAA, 5 and 8 (at $\left.1 \mathrm{mmol} \mathrm{L}^{-1}\right)$ on Cucumis sativa under greenhouse conditions after 22 days. Control (A), plants treated with NAA (B), plants treated with $5(C)$, and plants treated with $8(D)$

by reducing the formation of plastoquinone pool which affect the electron transfer in photosynthesis. ${ }^{43}$ Considering the similarities on the visual changes caused by compounds $\mathbf{5 , 8}$ and those reported for artemisinin, we hypothesize that some of the phytotoxic effect caused by $\mathbf{5}$ and $\mathbf{8}$ might be related to the peroxide group in its structure.

\section{Degradation of tetraoxane 5}

The degradation experiment for $\mathbf{5}$ was conducted for 22 days, under similar conditions employed in the greenhouse bioassay. The quantification of $\mathbf{5}$ was performed by HPLC, using the analytical conditions previously established and described in detail in the experimental part.

As observed from Figure 5, during the first day of experiment the concentration of $\mathbf{5}$ decreased by approximately $20 \%$. In the period of days 3 and 14 the concentration of 5 remained constant at approximately $58 \%$. After 14 days of experiment, the concentration of compound $\mathbf{5}$ decreased sharply, resulting in its total degradation after 22 days of experiment.

As previously stated, one of the objectives of this study was to investigate if $\mathbf{5}$ could, during its action, be converted into NAA. This conversion could occur via the aldehyde $\mathbf{6}$ that would be naturally oxidized. Although the chromatogram did not show any trace of $\mathbf{6}$ during the 22 days of experiment, an amount of NAA was observed from days 13 to 15 .

Since the substrate used in this experiment (sand) is inert, the detection of NAA clearly demonstrates that if $\mathbf{5}$ is indeed hydrolyzed into aldehyde 6, this is rapidly oxidized as proposed in Scheme 2. Another hypothesis is the direct degradation of $\mathbf{5}$ into NAA, via

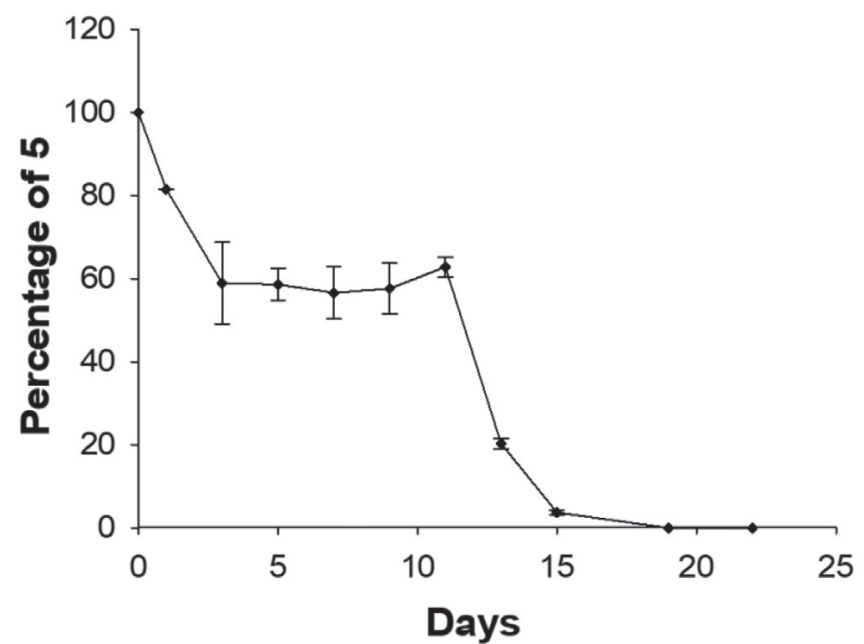

Figure 5. Percentage of tetraoxane 5 in contact with sand, at room temperature, during 22 days

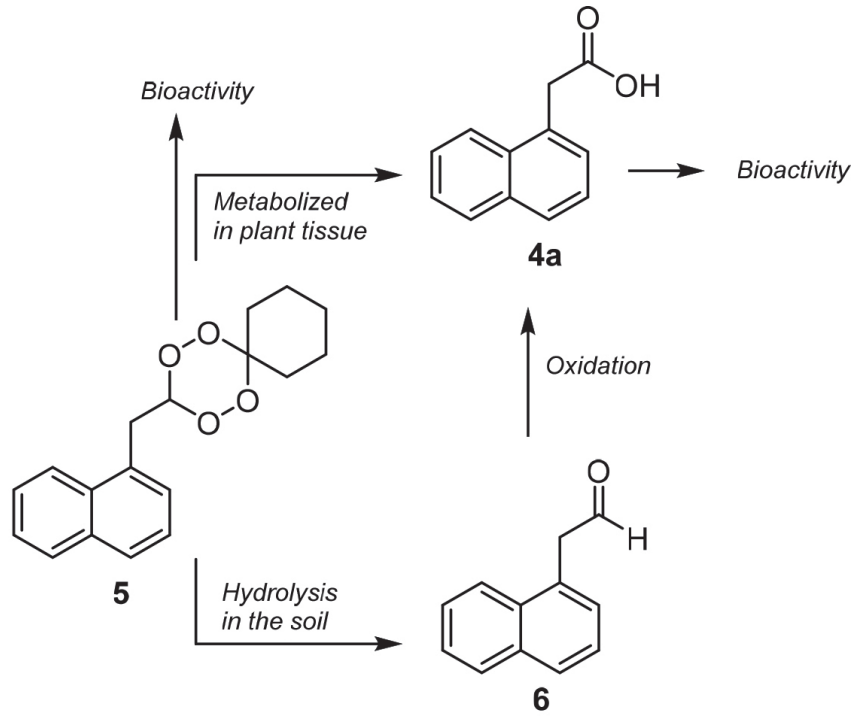

Scheme 2. Possible degradation pattern of tetraoxane 5

radical intermediates. Further experiments are required to elucidate this mechanism.

As tetraoxane $\mathbf{5}$ is degraded, but the expected product NAA is not accumulated during the 22 days of experiment, we conclude that NAA is degraded faster under the experimental conditions. Since sand is inert, this degradation must be due to some photo-induced process, in agreement with the literature that reported the photolysis of NAA resulting in four products. ${ }^{44,45}$ Concerning the degradation of NAA when applied in soil, the studies are very restricted. For example, 
it has been shown that it is converted, under aerobic conditions, by microorganisms into catechol and naphthol in less than 72 hours. ${ }^{46}$

The results from the degradation experiment and the changes observed in the biological assays with 5 give some clues about its mode of action. From the observed chlorosis and necrosis, we suggest that tetraoxane 5 might act via a mechanism involving the formation of ROS, via decomposition of its peroxide moiety. The other effects as epinasty and roots nodulation suggest the compound is degraded into NAA in the soil or in the plant, acting as an auxin-type herbicide.

\section{MATERIAL AND METHODS}

\section{Chemicals, instruments and experimental procedures}

All reagents and solvents used for these experiments were procured from commercial sources (Sigma-Aldrich, Milwaukee, Wisconsin, USA). The ${ }^{1} \mathrm{H}$ and ${ }^{13} \mathrm{C}$ NMR spectra were recorded on a Bruker NMR spectrometer (400 MHz and $100 \mathrm{MHz}$, respectively). All samples were dissolved in deuterated chloroform, using tetramethylsilane (TMS) as internal standard $(\delta=0)$. The IR spectra were obtained using an Aminco Bowmen Adrid Zone infrared spectrometer (Thermofischer, Waltham, MA, USA). High-resolution mass spectra were obtained in a LC/MS-TOF (Agilent 6210, Santa Clara, CA, USA) using electrospray ionization (ESI). Melting points are uncorrected and were measured in a digital melting point apparatus (MQAPF-302, Microquímica Equipamentos, Rio de Janeiro, Brazil). Analytical thin layer chromatography analyses were carried out using aluminum packed pre-coated silica gel plates Polygram-UV254. All compounds purifications were carried out by column chromatography using silica gel (70-230 mesh) as stationary phase.

Synthesis of 1,1-dihydroperoxyciclohexane (8). To a one-neck round bottom flask were added cyclohexanone $(0.5 \mathrm{~g}, 5.1 \mathrm{mmol})$, acetonitrile $(8 \mathrm{~mL})$, an aqueous solution of hydrogen peroxide $(56 \%$ $\mathrm{v} / \mathrm{v}, 2.9 \mathrm{~g}, 51 \mathrm{mmol})$ followed by tin chloride $(0.05 \mathrm{~g}, 20 \mathrm{~mol} \%)$. The mixture was kept under magnetic stirring at room temperature for $1.5 \mathrm{~h}$. The reaction was quenched by the addition of a saturated aqueous solution of sodium bicarbonate $(25 \mathrm{~mL})$ and extracted with dichloromethane $(3 \times 25 \mathrm{~mL})$. The organic layers were combined and dried over anhydrous $\mathrm{MgSO}_{4}$. After filtration, the solvent was removed under reduced pressure at $40{ }^{\circ} \mathrm{C}$. The compound was obtained as a white solid (694 mg, $4.69 \mathrm{mmol}, 92 \%)$. M.p. $40-42{ }^{\circ} \mathrm{C}$. Lit. ${ }^{47}$ IR $\left(\mathrm{cm}^{-1}\right)$ : 3422, 2940, 2862, 2676, 1710, 1449, 1353, 1051. ${ }^{1} \mathrm{H}-\mathrm{NMR}\left(400 \mathrm{MHz}, \mathrm{CDCl}_{3}\right.$ ) $\delta: 1.40-1.80$ (m, 10H, H-2, H-3, H-4, $\mathrm{H}-5, \mathrm{H}-6), 9.5$ (s, 2H, OH). ${ }^{13} \mathrm{C}-\mathrm{RMN}\left(100 \mathrm{MHz}, \mathrm{CDCl}_{3}\right) \delta: 22.6$ (C-3, C-5); 25.5 (C-4); 29.9 (C-2, C-6), 111.3 (C-1).

Synthesis of 2-(naphthalen-1-yl) ethan-1-ol. In a round bottom flask kept at $0{ }^{\circ} \mathrm{C}$, compound $4 \mathbf{a}(1.0 \mathrm{~g}, 5.3 \mathrm{mmol})$, lithium aluminum hydride $(0.4 \mathrm{~g}, 10.7 \mathrm{mmol})$ and dry THF $(10 \mathrm{~mL})$ were added. The cold bath was removed and the system was kept stirring under argon atmosphere at room temperature for $12 \mathrm{~h}$. Next, the mixture was diluted with diethyl ether $(40 \mathrm{~mL})$ and cooled at $0{ }^{\circ} \mathrm{C}$. Subsequently, $1.8 \mathrm{~mL}$ of water were slowly added, followed by $1.8 \mathrm{~mL}$ of aqueous solution of $\mathrm{NaOH}(15 \% \mathrm{v} / \mathrm{v})$. The ice bath was removed and the mixture maintained under magnetic stirring until it reached room temperature. Finally, the mixture was dried over anhydrous $\mathrm{MgSO}_{4}$ and concentrated under reduced pressure to afford the required product as yellow oil (900 mg, $5.5 \mathrm{mmol}, 95 \%)$. Lit. ${ }^{48} \mathrm{IR}\left(\mathrm{cm}^{-1}\right)$ : 3369, 3049, 2947, 2878, 1596, 1510. ${ }^{1} \mathrm{H}-\mathrm{NMR}\left(400 \mathrm{MHz}, \mathrm{CDCl}_{3}\right.$ ) $\delta: 1.52(\mathrm{~s}, 1 \mathrm{H}, \mathrm{OH}), 3.23\left(\mathrm{t}, 2 \mathrm{H}, J_{9,10}=6.7 \mathrm{~Hz}, \mathrm{H}-9\right) ; 3.91(\mathrm{t}, 2 \mathrm{H}$, $\left.J_{10,9}=6.7 \mathrm{~Hz}, \mathrm{H}-10\right) ; 7.27-7.41$ (m, 2H, H-2, H-3); 7.42-7.45 (m, 2H, H-6, H-7); 7.65 (bd, 1H, J = 8.0 Hz, H-4); 7.77 (m, 1H, H-5); 7.96 (bd, $1 \mathrm{H}, J=8.0 \mathrm{~Hz}, \mathrm{H}-8) .{ }^{13} \mathrm{C}-\mathrm{NMR}\left(100 \mathrm{MHz}, \mathrm{CDCl}_{3}\right) \delta: 36.6(\mathrm{C}-9)$; 63.3 (C-10);123.5 (C-2); 125.7 (C-8); 125.9 (C-6); 126.3 (C-7); 127.4 (C-3); 127.5 (C-4); 129.1 (C-5); 132.3 (C-4a); 134.2 (C-8a); 134.5 (C-1). MS-EI $m / z: 172.10$.

Synthesis of 2-(naphthalen-1-yl)acetaldehyde (6) using the Dess-Martin methodology. To a round bottom flask were added 2-(naphthalen-1-yl)ethan-1-ol (0.1 g, $0.9 \mathrm{mmol})$ and dichloromethane $(5 \mathrm{~mL})$. The mixture was cooled at $0{ }^{\circ} \mathrm{C}$ and stirred for $5 \mathrm{~min}$. Then the Dess-Martin periodinane $(0.57 \mathrm{~g}, 1.4 \mathrm{mmol})$ was added and the temperature was raised to $25^{\circ} \mathrm{C}$. The mixture was stirred during $1.5 \mathrm{~h}$ and then diluted with dichloromethane $(10 \mathrm{~mL})$. This reaction mixture was quenched with a saturated solution of $\mathrm{NaHCO}_{3}(10 \mathrm{~mL})$ The aqueous solution was extracted with dichloromethane $(3 \times 10 \mathrm{~mL})$, and then the organic layers were collected and filtered over anhydrous $\mathrm{Na}_{2} \mathrm{SO}_{4}$. The solvent was removed by distillation under reduced pressure. Purification of the product was carried out by filtering the mixture over a plug of neutralized silica gel (previously treated with a $10 \%$ aqueous solution of $\mathrm{NH}_{4} \mathrm{OH}$ ). The product was obtained as a yellow oil (131 mg, $0.77 \mathrm{mmol}, 86 \%)$.

Synthesis of (6) using BAIB and TEMPO. To a $50 \mathrm{~mL}$ round bottom flask were added 2- (naphthalen-1-yl) ethan-1-ol (0.5 g, $2.9 \mathrm{mmol}$ ), bis-acetoxyiodobenzene (BAIB) (1.3 g, $3.9 \mathrm{mmol})$ and (2,2,6,6-tetramethylpiperidin-1-yl)oxyl (TEMPO) (4.5 mg, $0.29 \mathrm{mmol})$ in dichloromethane $(10 \mathrm{~mL})$. The reaction mixture was kept under stirring for $12 \mathrm{~h}$, and then diluted with dichloromethane $(10 \mathrm{~mL})$, and quenched by addition of an aqueous saturated solution of $\mathrm{Na}_{2} \mathrm{SO}_{3}(10 \mathrm{~mL})$. The organic layer was separated and washed with an aqueous saturated solution of $\mathrm{NaHCO}_{3}(10 \mathrm{~mL})$, and dried over anhydrous $\mathrm{Na}_{2} \mathrm{SO}_{4}$. The solvent was removed by distillation under reduced pressure. Purification was carried out by distillation $\left(160^{\circ} \mathrm{C}, 1 \mathrm{~atm}\right)$, affording the required product as yellow oil $(310 \mathrm{mg}$, $1.82 \mathrm{mmol}, 63 \%)$.

Data for 2-(naphthalen-1-yl)acetaldehyde $(\mathbf{6}){ }^{49} \mathrm{IR}\left(\mathrm{cm}^{-1}\right): 3361$, 3055, 2947, 2873, 1610, 1515. ${ }^{1} \mathrm{H}-\mathrm{NMR}\left(400 \mathrm{MHz}, \mathrm{CDCl}_{3}\right)$ \&: 3.87 (d, $\left.2 \mathrm{H}, J_{9,10}=2.4 \mathrm{~Hz}, \mathrm{H}-9\right)$; 7.29-7.44 (m, 4H, H-2, H-3, H-6, H-7); 7.71-7.78 (m, 3H, H-4, H-5, H-8); 9.65 (t, 1H, J $J_{10,9}=2.4$ Hz, H-10). ${ }^{13} \mathrm{C}-\mathrm{NMR}\left(100 \mathrm{MHz}, \mathrm{CDCl}_{3}\right)$ \&: 48.5 (C-9); 123.7(C-8); 125.7 (C-3); 126.3 (C-7); 126.9 (C-6); 128.6 (C-4); 129.1 (C-2); 130.4 (C-5); 132.4 (C-4a); 134.1 (C-8a); 139.5 (C-1); 199.9 (C-10). MS-EI m/z: 170.07

Synthesis of 3-(naphthalen-1-ylmethyl)-1,2,4,5-tetraoxaspiro[5.5] undecane $(\mathbf{5})$. To a $50 \mathrm{~mL}$ round bottom flask were added compounds $8(0.4 \mathrm{~g}, 2.7 \mathrm{mmol})$ and $\mathbf{6}(0.3 \mathrm{~g}, 1.8 \mathrm{mmol})$ and $10 \mathrm{~mL}$ of dichloromethane. The mixture was cooled to $-78{ }^{\circ} \mathrm{C}$ and stirred for $30 \mathrm{~min}$. Then, a solution of $\mathrm{H}_{2} \mathrm{SO}_{4}$-acetonitrle $9: 1(6.5 \mathrm{~mL}$, $13.3 \mathrm{mmol}$ ) was added dropwise. The reaction was kept under magnetic stirring for 2 hours at $-78{ }^{\circ} \mathrm{C}$, before being quenched by addition of a saturated solution of $\mathrm{NaHCO}_{3}(15 \mathrm{~mL})$. The aqueous phase was extracted with dichloromethane $(3 \times 10 \mathrm{~mL})$. Then, the organic phases were combined, dried over anhydrous $\mathrm{MgSO}_{4}$ and concentrated under reduced pressure to provide the crude product as a white solid. Further fractionation of this crude mixture by silica gel column chromatography, eluting with a mixture of hexane: chloroform $(7: 3 \mathrm{v} / \mathrm{v})$ resulted in the required compound $\mathbf{5}$ as a white solid (124.3 mg, $0.41 \mathrm{mmol}, 23 \%$ ) and the known tetraoxane 3 also as a white solid (123.4 mg, $0.54 \mathrm{mmol}, 20 \%) .{ }^{15}$

Datafor (5): White solid. M.p.: 162.0-163.1 ${ }^{\circ} \mathrm{C} . \mathrm{IR}\left(\mathrm{cm}^{-1}\right): 3048$, 2926, 2856, 1510, 1445. ${ }^{1} \mathrm{H}-\mathrm{NMR}\left(400 \mathrm{MHz}, \mathrm{CDCl}_{3}\right) \delta: 1.28-1.66(\mathrm{~m}$, $8 \mathrm{H}, \mathrm{H}-16, \mathrm{H}-17$, H-18, H-19); 2.37 (t, 2H, $\left.J_{20}=6.0 \mathrm{~Hz} \mathrm{H}-20\right) ; 3.33$ (d, 
$\left.2 \mathrm{H}, J_{10.9}=4.7 \mathrm{~Hz}, \mathrm{H}-9\right) ; 6.14\left(\mathrm{t}, 1 \mathrm{H}, J_{9.10}=4.7 \mathrm{~Hz} ; \mathrm{H}-10\right) ; 7.26-8.01$ (m, 7H, H-2, H-3, H-4, H-5, H-6, H-7, H-8). ${ }^{13} \mathrm{C}-\mathrm{NMR}(100 \mathrm{MHz}$,

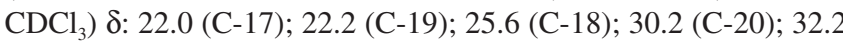
(C-16); 33.9 (C-9); 108.3 (C-10); 109.1 (C-13), 123-133 (from C-1 to C-8). HRMS (ESI-TOF) $\mathrm{m} / z[\mathrm{M}+\mathrm{H}]^{+}$: Calculated for $\mathrm{C}_{18} \mathrm{H}_{21} \mathrm{O}_{4}{ }^{+}$: 301.1434; found: 301.1407 .

Data for (3): White solid. M.p.: 129.2-130.2 ${ }^{\circ} \mathrm{C}$. Lit.: ${ }^{15}$ 129.2-130.1 ${ }^{\circ} \mathrm{C} .{ }^{1} \mathrm{H}-\mathrm{NMR}\left(400 \mathrm{MHz}, \mathrm{CDCl}_{3}\right) \delta: 1.40-2.80(\mathrm{~m}, 18 \mathrm{H}$ H-7b, H-8, H-9, H-10, H-11b, H-12b, H-13, H-14, H-15, H-16b) 2.10-2.50 (m, 4H, H-7a, H-11a, H-12a, H-16a). ${ }^{13} \mathrm{C}\left(100 \mathrm{MHz}, \mathrm{CDCl}_{3}\right)$ $\delta: 22.3$ (C-9, C-14), 25.6 (C-8, C-10, C-13, C-15), 30.9 (C-11, C-16), 31.8 (C-7, C-12), 108.4 (C-3, C-6). HRMS m/z (M+Na+): calcd for $\mathrm{C}_{12} \mathrm{H}_{20} \mathrm{NaO}_{4}, 251.1254$; found, 251.1221.

\section{Greenhouse herbicide assay}

The stock solutions of the compound to be tested $\left(1 \mathrm{mmol} \mathrm{L}^{-1}\right)$ were prepared by dissolving the samples in a mixture of penta-3one $(50 \mu \mathrm{L})$, the surfactant Tween $80^{\circledR}(100 \mu \mathrm{L})$ and distilled water $(50 \mathrm{~mL})$. This suspension was shaken for $1 \mathrm{~min}$, and then transferred to a $250 \mathrm{~mL}$ volumetric flask and the volume was completed with distillated water. This mixture was diluted in water to the final concentration of $0.125 \mathrm{mmol} \mathrm{L}^{-1}$. Assays were carried out using Cucumis sativa, Sorghum bicolor, Iponomea acuminate, Bidens pilosa, Solanum americanum and Alternanthera ficoidea as target species. Plastics pots $(0.25 \mathrm{~mL})$ were filled with washed sand $(140 \mathrm{~g})$, approximately 5 seeds of each species, followed by $5 \mathrm{~mL}$ solution of each active ingredient (a.i.) solution to be tested. The experiment was carried out in triplicate, in greenhouse conditions. Each pot was irrigated three times per day. Micro and macronutrients were provided by adding Hogland solution every 5 days. Finally, after 22 days, plants were harvested. The roots and shoots were separated and dried at $70{ }^{\circ} \mathrm{C}$ until constant weight. Next, both roots and shoots dry weight was obtained using an analytical scale. The percentage of growth inhibition was calculated with respect to the mass of the control. The data were analyzed using the Sigma Plot 12.5 software.

\section{Degradation of tetraoxane 3-(naphthalen-1-ylmethyl)-1,2,4,5- tetraoxaspiro[5.5] undecane (5)}

Chemicals and solvents. Compounds $\mathbf{5}$ and $\mathbf{6}$ were prepared as previously described while NAA was purchased from Sigma-Aldrich (Milwaukee, Wisconsin, USA). In regard with its store conditions compound 5 and $\mathbf{6}$ were kept at $0{ }^{\circ} \mathrm{C}$ whereas NAA was stored at room temperature. HPLC solvents acetonitrile and methanol and trifluoroacetic acid were procured from Sigma-Aldrich (Milwaukee, Wisconsin, USA). Purified water was generated by a Millipore Direct-Q ultrapure water system.

Equipment. All the HPLC analyses were performed in a Shimadzu LC-20A series equipment. The HPLC system was equipped with Shimadzu UV diode array detector (SPD-20A), a vacuum degasser, a binary pump (LC-20AT) and an autoinjector (SIL-10AF). The separations were carried out using a Phenomenex C18 column $(2.6 \mu \mathrm{m}$ size particles, length $100 \mathrm{~mm}$, i.d. $3 \mathrm{~mm}$ ). All data were processed with the LC solution software 1.23 SPI.

Standard solutions. Stock solutions of compounds 5, $\mathbf{6}$ and NAA ( 2 mmol L ${ }^{-1}$ concentration) were prepared by dissolving 5-10 mg of each compound in $10 \mathrm{~mL}$ of water, and $30 \mu \mathrm{L}$ of Tween 80 . Once the solutions were prepared, they were kept in an ultrasound baths from 3 to 5 minutes. Furthermore, standard solutions of compound 5 were prepared for calibration curves in 6 concentrations $(0.0625,0.125$, $\left.0.250,0.500,1.00,2.000 \mathrm{mmol} \mathrm{L}^{-1}\right)$.

Experiment conditions and extraction methodology. In a falcon tube were added $1 \mathrm{~g}$ of sand and $1 \mathrm{~mL}$ of the compound standard solution $\left(2 \mathrm{mmol} \mathrm{L}^{-1}\right)$. The resulting mixture was homogenized for 2-3 min. A total of 33 tubes were prepared and stored at room temperature and with light exposition. The experiment was maintained during 22 days, and the samples for analysis were taken every 2 days.

To extract the compounds, the full volume of the aqueous phase was taken from the falcon tube, centrifuged and collected. Then, $1 \mathrm{~mL}$ of acetonitrile was added to the remained sand. This new mixture was kept in an ultrasound bath for 1 minute. After that, the sample was centrifuged and the full volume of the liquid phase was taken. This solution was combined with the water phase previously collected. The new mixture was filtered over a SPE cartridge, then $3 \mathrm{~mL}$ of acetonitrile were eluted through the cartridge. All fractions were combined and an aliquot of this resulting dilution was used for HPLC analysis. The samples were injected using a mixture of acetonitrile/water 95:5 as eluent. Compound $\mathbf{5}$ was detected at $81 \mathrm{~min}$ while NAA was detected at $70.1 \mathrm{~min}$.

\section{CONCLUSIONS}

In summary, we have developed a synthetic procedure to convert commercial NAA into a new tetraoxane $\mathbf{5}$. In a pre-emergency bioassay, the new tetraoxane is effective in inhibiting the growth of several important weeds. The compound seems to act via auxinic path and also as a photosystem inhibitor. Moreover, some synthetic precursors of $\mathbf{5}$ also have high phytotoxic activity, suggesting that if it is degraded it could provide other species that could continue acting as herbicides.

\section{SUPPLEMENTARY MATERIAL}

The spectra of ${ }^{1} \mathrm{H}-\mathrm{NMR}$ and ${ }^{13} \mathrm{C}-\mathrm{NMR}$ of tetraoxane $\mathbf{5}$ and the data related with biological assays are available at http://quimicanova. sbq.org.br, as PDF file and open access.

\section{ACKNOWLEDGMENT}

We are grateful to the following Brazilian agencies: Conselho Nacional de Desenvolvimento de Científico e Tecnológico (CNPq) for research fellowships and financial support, and Fundação de Amparo à Pesquisa de Minas Gerais (FAPEMIG) for financial support. We also thank Dr. Fyaz M. D. Ismail (Liverpool John Moores University, UK) and Dr. Amanda Silva de Miranda (UFMG), for critical suggestions on the manuscript.

\section{REFERENCES}

1. Coob, A. H.; Reade, J. P. H.; Herbicides and plant physiology, $2^{\text {nd }}$ ed., Wiley-Blackwell: Oxford, 2010.

2. Duke, S. O.; Pest. Manag. Sci. 2012, 68, 505.

3. Tomlin, C.; The Pesticide Manual, 10 ${ }^{\text {th }}$ ed., RSC: Surrey, 1994.

4. http://www.weedscience.com/Graphs/ChronologicalIncrease.aspx, accessed May 2020.

5. Jugulam, M.; Shyam, C.; Plants 2019, 8, 417.

6. Kramer, K. L.; J. Anthrop. Res. 2019, 75, 472.

7. Peterson, M.; Pest Manage. Sci. 2017, 74, 2246.

8. Duke, S. O.; Evidente, A.; Vurro, M.; Pest. Manag. Sci. 2019, 75, 2299.

9. Barbosa, L. C. A.; Maltha, C. R. A.; Lage, M. R.; Barcelos, R. C.; Dona, A.; Carneiro, J. W. M.; Forlani, G.; J. Agric. Food Chem. 2012, 60, 10555 . 
10. Demuner, A. J.; Barbosa, L. C. A.; Veloso, D. P.; Alves, D. L. F.; Howarth, O. W.; J. Nat. Prod. 1996, 59, 770

11. Barbosa, L. C. A.; Ferreira, M. L.; Demuner, A. J.; Silva, A. A.; Pereira, R. D. C.; Maltha, C. R. A.; Quim. Nova 2001, 24, 751.

12. Knudsmark, K.; Jessing, K.; Duke, S.; Cedergreeen, N.; J. Chem. Ecol. 2014, 40, 100

13. Constantino, M.; Beltrame, M.; Gil-Valdo, J.; Zuckerman, J.; Synth. Commun. 1996, 26, 321.

14. Barbosa, L.C.A.; Maltha, C. R. A.; Cusati, R.C.; Teixeira, R. R.; Rodrigues, F.F.; Drew, M.G.B.; Isamail, F. M. D.; J. Agric. Food Chem. 2009, 57, 10107.

15. Cusati, R.; Barbosa, L. C. A.; Maltha, C. R. A,; Demuner, A. J.; Oliveros-Bastidas, A.; Silva, A. A.; Pest Manage. Sci. 2015, 71, 1037.

16. Cusati, R.; Barbosa, L. C. A.; Maltha, C. R. A.; Demuner, A. J.; Silva, A. A.; $B r$ 102014001715-1, 2019

17. Guan, A.; Liu, C.; Yang, X.; Dekeyser, M.; Chem. Rev. 2014, 114, 7079.

18. Nutman, P. S.; Thorton, H. G.; Nature 1945, 155, 498.

19. Grossmann, K.; Trends. Plant. Sci. 2000, 5, 506.

20. Jugulam, M.; Hall, J.C.; Johnson, W. G.; Kelley, K. B.; Riechers, D. E.; Crops. Weed Sci. 2011, 59, 445

21. Jeschke, P.; Pest Manage. Sci. 2015, 72, 210.

22. Pallet, K.; Cramp, S.; Little, J.; Veerasekaran, P.; Crudace, A.; Slater, A.; Pest Manage. Sci. 2001, 57, 127.

23. Chandrasekhar, S.; Suresh, K.; Muraldhar, B.; Tetrahedron Lett. 1998, 39, 909.

24. Arimoto, H.; Ohba, S.; Nishiyama, S.; Yamamura, S.; Tetrahedron Lett. 1994, 67, 4581.

25. Pratt, N.; Zhao, Y.; Hitchcock, S.; Albizati, K.; Synlett. 1991, 5, 361.

26. Corey, E. J.; Williams, J.; Tetrahedron Lett. 1975, 16, 2647.

27. De Mico, A.; Margarita, R.; Parlanti, L.; Vescovi, A.; Piancatelli, G.; J. Org. Chem. 1997 62, 6974.

28. Baldaia, A.; Dissertação de Mestrado, Universidade Federal de Minas Gerais, Brasil, 2015.

29. Opsenica, D.M.; Terzić, N.; Smith, P. L.; Yang, Y.; Anova, L.; Smith, K. S.; Šolaja, B. A.; Bioorg. Med. Chem. 2008, 16, 7039.

30. Terent'ev, A.O.; Borisov, D.; Vil, V.; Dembitsky, V. M.; Beilstein J. Org. Chem. 2014, 10, 34
31. Valero-Antolínez, I., Dissertação de Mestrado, Universidade Federal de Minas Gerais, Brasil, 2015.

32. Tarzona, J.V.; Court-Marques, D.; Titimani, M.; Reich, H.; Pfeil, R.; Istace, F.; Crivellente, F.; Arch Toxicol. 2017, 91, 2723.

33. Kraemer, A.F.; Marchesan, E.; Avila, L.A.; Machado, S.L.O.; Grohs, M.; Massoni, P.F.S.; Sartori, G.M.S.; Planta Daninha 2009, 27, 58

34. Todorović, N. M.; Stefanović, M.; Tinant, B.; Declercq, J. P.; Makler, M. T.; Šolaja, B.A.; Steroids 1996, 61, 688.

35. Pereira, G. A. M.; Barcellos, L. H.; Gonçalves, V. A.; Silva, D. V.; Silva A. A.; Planta Daninha 2017, 35, 1.

36. Freitas, R.; Berger, P.G.; Ferreira, L. R.; Silva, A. C.; Cecon, P.R.; Silva, M. P.; Planta Daninha 2009, 24, 339.

37. Pereira, M.; Hernández, D.; Giancotti, P.; Alves, P.; Revista Brasileira de Ciências Agrárias 2010, 5, 474.

38. https://ainfo.cnptia.embrapa.br/digital/bitstream/item/162704/1/CT132OL.pdf, accessed May 2020.

39. Forest, P.; Norman, M.; Weed Sci. 1991, 39, 458

40. Sant’ana, G. L.; 2015. Dissertação de Mestrado, Universidade Federal de Viçosa, Brasil, 2015.

41. Pereira, D.; Rodrigues, R.; Rodrigues, F.; Rocha, A.; Silva, D.; Barbosa, J.; Nery, M.; Rev. Ceres 2013, 60, 354

42. Yan, Z.; Wang, D.; Ding, L.; Cui, H.; Jin, H.; Yang, X.; Yang, J.; Qin, B.; Plant Physiol. Biochem. 2015, 88, 53.

43. Bharati, A.; Kar, M.; Sabat, S.; PLoS One 2012, 7,1.

44. https://archive.epa.gov/pesticides/reregistration/web/pdf/naa_red.pdf, accessed May 2020.

45. http//www.efsa.europa.eu/efsajournal.htm, accessed May 2020.

46. Proctor, M.; Plant Soil 1963, 3, 338.

47. Terent'ev, O.; Platonov, M. M.; Tursina, A. I.; Chernyshev, V. V.; Nikishin, G. I.; J. Org. Chem. 2008, 73, 3169.

48. Toyao, T.; Hakim Siddiki S. M. A.; Touchy, A. S.; Onodera, W.; Kon, K.; Morita, Y.; Kamachi, T.; Yoshizawa, K.; Shimizu, K.; Chem. Eur. J. 2017, 23, 1001

49. Terzic, V.; Pousse, G.; Méallet-Renault, R.; Grellier, P.; Dubois, J.; J. Org. Chem. 2019, 84, 8542. 